\title{
Becoming a "Real University:" The Strategic Benefits of Adding Football for NCAA Division I Institutions
}

\author{
Darren Kelly and Marlene A. Dixon \\ The University of Texas at Austin
}

\begin{abstract}
In the midst of an economic crisis leading to extensive cuts in college athletics, at least 38 colleges in the past five years have either added or have plans to add football to their athletic programs. Of particular interest are schools that have traditionally been known as "commuter universities." In response to increased competition from other colleges, many of these schools are adding football as a part of a larger strategic vision for creating a "better college product." Using resourcebased (Barney, 1991) and institutional theories (DiMaggio \& Powell, 1983), this study seeks to understand the strategic arguments used and the benefits sought by universities adding football on their campuses. This study employs qualitative content analysis methodology (Marshall \& Rossman, 2006; Miles \& Huberman, 1994) using publically available football feasibility studies from six NCAA Division I universities that have added (or have advertised plans to add) football over the past five years. Results indicate that football is seen as a vehicle for creating a sense of community and enhancing the institutional value of universities. Results also show that the dominant strategic rationale for adding these football programs is more consistent with institutional than resource-based theory. Implications of such strategy include an overemphasis on sport, and a corresponding lack of attention paid to other more innovative solutions to broader campus issues.
\end{abstract}

For NCAA Division I college athletic programs, it has become increasingly important for athletic directors and university administrators to use management principles to help create long-term strategies for adding market value, sustainable profits, and increased prestige to their programs and institutions. The competitive marketplace in college athletics, therefore, provides a rich context for examining strategic management in sport and higher education, as well as the issues associated with the short and long term viability of college athletics (particularly football) on college campuses. The purpose of this study is to examine the perceived benefits of football programs to a university and the perspective used in defending or promoting the football program as part of a university's strategic plans. This study will contribute to theory by examining the kinds of arguments used for adding football in a competitive higher education marketplace. It will contribute to practice by outlining the advantages and disadvantages of adding football, and

The authors are with Sport Management, The University of Texas at Austin, Austin, TX. 
showing how institutionalized thinking may preclude the identification of more creative competitive strategies.

\section{Background of College Football}

On Saturdays in the fall, hundreds of thousands of students, alumni, and fans gather at stadiums nationwide not only to watch their favorite team play, but also to socialize with fellow supporters of their school in the stands, around tailgates, or even in luxury suites. Student groups, fraternities, and sororities can also be seen socializing with one another and organizing functions around football games. Many organizations, businesses, and university departments use football games to cultivate potential donors or help broker business deals with clients. Over the last twenty to thirty years, the potential for earning millions of dollars from football has grown tremendously.

Football is seen as a major revenue producer for universities large and small, and universities at times go to great lengths to strengthen or improve their football programs. For example, in 2008, the University of Texas football team earned \$87.6 million dollars in total revenues, more than any other program in the nation (Maher, 2009). Many schools consider football as a revenue producing sport (along with men's basketball) that helps provide financial resources for other varsity athletic teams. Thus, athletic departments spend large sums of money on operating expenses for football including coaches salaries, facilities, travel, and recruiting, hoping that their investment will pay off in ticket sales, donations, and merchandise revenue (Roy, Graeff, \& Harmon, 2008).

This multimillion dollar annual investment in football, however, is difficult to maintain, even in the best of times. The current economic situation is making it even harder for college athletic departments to sponsor multiple sports, including football. Some schools have opted to raise student fees and provide athletic departments with other subsidies to help continue to field varsity sports (Longman, 2009). Other schools have made substantial cuts. For example, Stanford University recently cut $13 \%$ of their athletic staff (FitzGerald, 2009). Harvard University's \$11 billion reduction in their endowment has forced the athletic department to reduce their athletic programs (Lavelle, 2010). The sports usually affected by cuts are nonrevenue programs such as golf, wrestling, and soccer. However, football has not been spared from the recent economic downturn. At season's end in December 2009, both Northeastern and Hofstra decided to drop their football programs after more than 70 years of competition (Armstrong, 2009). Both schools cited the need to prioritize and redirect resources toward other academic and athletic programs. These and other schools that have chosen not to offer football feel that these financial resources can be better used for other purposes.

Despite the fact that many schools are making difficult decisions regarding cutbacks to athletic budgets, programs, and staff, a number of universities are still considering adding football to their athletic offerings, and university presidents report that they continue to receive pressure from various constituencies to do so (Knight Commission on Intercollegiate Athletics, 2009). A newspaper and internet search revealed that at least 38 universities in the past five years have either added or have begun planning to add football to their athletic programs, including those at NCAA Divisions I, II, \& III, and NAIA-affiliated institutions as shown in Table 1. 
Table 1 Colleges and Universities That Have Added or Plan To Add Football Programs Between 2004-2014

\begin{tabular}{|c|c|c|c|}
\hline School & Location & Level & $\begin{array}{l}\text { First } \\
\text { Season }\end{array}$ \\
\hline Anna Maria College & Paxton, MA & NCAA Division III & 2009 \\
\hline Becker College & Leicester, MA & NCAA Division III & 2005 \\
\hline Birmingham-Southern College & Birmingham, AL & NCAA Division III & 2007 \\
\hline Campbell University & Buies Creek, NC & NCAA Division I-FCS & 2008 \\
\hline Castleton State College & Castleton, VT & NCAA Division III & 2009 \\
\hline Cleveland State University & Cleveland, $\mathrm{OH}$ & NCAA Division I-FCS & 2012 \\
\hline Colorado State Univ._-Pueblo & Pueblo, CO & NCAA Division II & 2008 \\
\hline Concordia University Ann Arbor & Ann Arbor, MI & NAIA & 2010 \\
\hline Dordt College & Sioux Center, IA & NAIA & 2008 \\
\hline Finlandia University & Hancock, MI & NCAA Division III & 2012 \\
\hline Gallaudet University & Washington, DC & NCAA Division III & 2007 \\
\hline Georgia State University & Atlanta, GA & NCAA Division I-FCS & 2010 \\
\hline Grand View University & Des Moines, IA & NAIA & 2008 \\
\hline Hendrix College & Conway, AR & NCAA Division III & TBD \\
\hline Kentucky Christian University & Grayson, KY & NAIA & 2008 \\
\hline LaGrange College & LaGrange, GA & NCAA Division III & 2006 \\
\hline Lake Erie College & Painesville, $\mathrm{OH}$ & NCAA Division II & 2008 \\
\hline Lamar University & Beaumont, TX & NCAA Division I-FCS & 2010 \\
\hline LeMoyne-Owen College & Memphis, TN & NCAA Division II & 2011 \\
\hline Lincoln University & Oxford, PA & NCAA Division II & 2009 \\
\hline Lindsey Wilson College & Columbia, KY & NAIA & 2010 \\
\hline Marian College & Indianapolis, IN & NAIA & 2007 \\
\hline North Carolina Wesleyan & Rocky Mount, NC & NCAA Division III & 2005 \\
\hline Notre Dame College & South Euclid, OH & NAIA & 2009 \\
\hline Old Dominion University & Norfolk, VA & NCAA Division I-FCS & 2009 \\
\hline Pacific University & Forest Grove, OR & NCAA Division III & 2010 \\
\hline Presentation College & Aberdeen, $S D$ & NCAA Division III & 2011 \\
\hline Seton Hill University & Greensburg, PA & NCAA Division II & 2005 \\
\hline St. Vincent College & Latrobe, PA & NCAA Division III & 2006 \\
\hline Stevenson University & Owings Mills, MD & NCAA Division III & 2010 \\
\hline SUNY Maritime College & New York, NY & NCAA Division III & 2006 \\
\hline The College of St. Scholastica & Duluth, MN & NCAA Division III & 2008 \\
\hline Univ. of Texas at San Antonio & San Antonio, TX & NCAA Division I-FCS & 2011 \\
\hline University of New Haven & West Haven, CT & NCAA Division II & 2009 \\
\hline Univ. of North Carolina at Charlotte & Charlotte, NC & NCAA Division I-FCS & 2013 \\
\hline University of North Carolina at Pembroke & Pembroke, NC & NCAA Division II & 2007 \\
\hline University of South Alabama & Mobile, AL & NCAA Division I-FCS & 2010 \\
\hline University of the Incarnate Word & San Antonio, TX & NCAA Division II & 2009 \\
\hline
\end{tabular}


Colleges and universities are creating football exploration committees and even contracting with consulting companies that generate football feasibility studies that have cost as much as $\$ 65,000$ (Grillo, 2007). Clearly the effort and investment required to explore adding football during this economic climate shows that some university trustees, presidents, and other influential parties see football as a potential asset that can benefit the entire institution.

\section{Beyond Finances: Multiple Benefits of Football}

While financial benefits may provide the primary impetus for developing football programs, there may be some additional benefits that this sport brings (or is perceived to bring) to campus. Student recruitment, media exposure, and increased prestige are some of the common benefits that are attributed to big time college football (Roy, et al., 2008). Football has also been thought to rally a community of students, faculty/staff, alumni, and area residents around a common cause: victory for their alma mater or favorite college team (Toma, 2003).

Both tangible and intangible benefits from football can affect the status and viability of the universities in which they reside. Kretchmar (2009) referred to these perceived benefits among others as institutional values. Institutional values can sometimes be emphasized more in athletics-related decision-making than their counterpart, identified by Kretchmar as educational values. Educational values are associated with the lessons and skills that are learned from participating in sportfrom training, practicing, competing, traveling together, and so on (Kretchmar, 2009). While football may be, and usually is, used to enhance both types of value, either institutional or educational values may take precedence. Kretchmar argued that institutional ends often trump educational objectives, particularly when other sports are cut while additional resources are funneled into football and basketball. But the fact remains that football is commonly associated with powerful institutional values. For Presidents who have to worry about the welfare of their institutions, the addition of football (even during economic downturns) may still emerge as a promising, and perhaps even necessary, strategic option.

While many different types of colleges and universities are looking to add football, of particular interest is a sector of schools that have traditionally been known as "commuter universities" (e.g., Georgia State in Atlanta, GA, The University of Texas at San Antonio). These schools are typically urban or suburban and attract local students, but they do not provide many of the on-campus amenities found at so-called residential universities. Commuter universities typically do not have a great proportion of students who live on or around campus, but rather accommodate individuals who commute from work and residences in the surrounding areas. With a lower number of students on campus during the evenings and weekends, fewer traditional campus activities are offered compared with residential universities..

With more online and community colleges also attracting students, these commuter universities are facing increasing levels of competition. One response to this competition has been to increase efforts to enhance the campus experience. Accordingly, some of these schools are adding or planning to add football as a part of a larger strategic effort to create a "better college product" for potential consumers. That is, football is perceived by some to be a tool for gaining a competitive advantage in a crowded college marketplace (Roy, et al., 2008; Smart \& 
Wolfe, 2000). This fact raises two important issues that will receive attention in this article., . First, it is important to understand the perceived benefits associated with a football program. Or to put the matter in the form of a question, in what specific ways is football perceived to enhance the overall college product?

A second, but related issue is the strategic rationale for adding football. Management literature speaks to two theories that provide explanations for the implementation of competitive organizational strategies. One of them, the resource-based view (RBV), suggests that organizations seek to find resources that are valuable and hard to imitate to gain a competitive advantage (Barney, 1991). Under this view (which is more thoroughly outlined in the subsequent section), one would expect to see colleges looking for ways not just to add football, but to make it distinct, nonimitable, and aligned with other campus strategies geared toward attracting students. Another approach called Institutional Theory, suggests that organizations add a resource if they feel that other organizations offer it, and that any failure to follow suit puts them at a competitive disadvantage (DiMaggio \& Powell, 1983; Goff, 2000). Under this theory, one would expect efforts to be made not at distinction or strategic integration, but at adding the resource with minimum cost (Goff, 2000).

When a RBV perspective is used, organizations can often grow in their creativity and new products or resources often blossom from innovative thinking (Barney, 1991). Colleges who adopt this perspective may find new ways to enhance their student experience via football or other strategic means. On the other hand, when an institutional perspective is used, creativity is often stifled, and organizations can become myopic in their thinking. Colleges who adopt this perspective may close off options for other solutions for enhancing campus life by adopting or copying practices that are already in place at other schools. While some have suggested that football is or can be used as a new and creative strategic resource on college campuses (e.g., Goff, 2000; Roy et al., 2008), we will argue that in most cases adding football has become attractive for reasons supported more by institutional theory than a resource-based view. This has the effect, among other things, of stifling innovation and creativity in looking for ways to enhance institutional and educational value on campus.

\section{Theoretical Framework: Strategic Management}

Admittedly, higher education is more than a business, and marketplace advantages over other academic institutions can be gained in ways that are compatible or incompatible with core values and purposes of higher education. Nevertheless, such strategic positioning is essential for college and university administrators. Leaders of institutions must look at potential assets like football in ways that transcend their purely educational value. As noted, one such perspective on strategic management is identified as the resource-based view (RBV). RBV has its roots in economic and business literature seeking to explain success in terms of capabilities or assets that are specific to a firm or organization. As explained above, according to the RBV (Barney, 1991), firms identify and use a particular resource to gain a sustainable competitive advantage over other firms in their particular marketplace. That is, RBV theorists argue that the key to gaining an advantage over other firms is to possess and deploy certain key resources in the marketplace (Fahy, 2000). Not every resource, however, is considered a key competitive resource. Barney 
(1991) stated that resources must be valuable, rare, hard to imitate, and not substitutable. Similarly, Fahy (2000) argued that advantage-creating resources include not only the resources themselves, but also their specific characteristics and the implementation thereof.

One example of the application of RBV to college athletics can be found in Smart and Wolfe's (2000) research where the authors argued that athletic programs in and of themselves were not a source of sustainable competitive advantage. Rather certain elements in the appropriation of teams were able to create an advantage, elements that were perceived as valuable by the consumer, that were not easy to replicate, and that were relatively rare. Such resources are difficult both to find and implement. Particularly in this tight economy, universities seeking a competitive edge among their peers by adding and deploying football on their campuses, yet without ensuring that their product is valuable, rare, and nonimitable, will probably not gain a competitive advantage. Those resources, it can be argued, could be used more effectively elsewhere.

For strategic growth in a field or industry, using a resource-based view, firms must find a balance between effectively using the resources they already have and developing new resources (Wernerfelt, 1984). Current resources can and should be reinvented and transformed to help maintain effectiveness (Auh \& Menguc, 2009). For example, universities may see the addition of football as a way to create a new resource while continuing to employ current athletic, academic and social resources to recruit students, earn prestige, and/or build a sense of community. Thus football would be integrated into an overall strategic plan using both new and current resources.

While RBV is a useful conceptual framework for analyzing the addition of football programs at colleges and universities, strategic implementation based on this theory has its limitations. One of the strengths of strategy based on RBV thinking is that it promotes the creation of resources (in this case new football programs) that enhance competitive advantage. Another strength is that firms (e.g., universities) can transform their image with the addition of a resource like a football team. An RBV strategy can also help an organization, particularly at the institutional level, create a unique position or niche within their industry.

However, RBV based strategies also introduce some challenges. For example, adding a new resource can be risky. If a school or an organization decides to add a major component as a new resource, and if that new component fails (including a lack of buy-in from important stakeholders), then the organization will have wasted much time, money, and effort. . In addition, administrators and leaders may have to spend yet even more time and money to correct their mistake and change strategic directions.

Another weakness of RBV specifically with regard to football programs is that other universities may be able to accomplish the same objectives (e.g., build a sense of community, build prestige, or recruit students) using other resources (Priem \& Butler, 2001). This becomes problematic if those other strategies are more effective at achieving the objectives and/or less expensive to implement. Last, RBV strategies are challenging because as the resource at issue becomes more imitable, it loses its distinct advantage and uniqueness. While it may be a testament to a football program's success and a compliment when imitated, over time the asset becomes less valuable because other universities are able to copy it for themselves. 
Unlike RBV, which stresses economic rational choices, institutional theory is characterized by normative rational choices (Oliver, 1997). According to Auh and Menguc (2009), institutional theory suggests that the actions of organizations are "shaped by social influences and pressures to conform" (p. 758). In addition, institutional theory argues that organizations are likely to become increasingly similar in structure, culture, and output as the result of coercive, mimetic, and normative isomorphic pressures (DiMaggio \& Powell, 1983). Thus, when organizations find a "key resource" it is often copied by other organizations until it becomes institutionalized. At this point other organizations may feel coerced to adopt that practice or resource whether it is efficient or optimal for their particular circumstances.. These organizations adopt the practice to maintain a sense of legitimacy and maintain or enhance prestige in their respective field or industry. In a sense, institutional theory suggests that organizations do not so much pursue competitive advantage, but seek to minimize competitive disadvantage. Such could be the case with college football. Its presence does not create an advantage over a nearby school, particularly one that also has football. But its absence may create a perception that it is not a fully legitimate or complete university. If it does not offer its students the opportunity to play or watch football, a major part of what is valuable about college life in the United States will be missing. The normative pressure to conform is considerable.

An example of the application of institutional theory in sport lies in Kikulis's (2000) research on governance changes in national sport organizations. Kikulis argued that pressure from the government, legal organizations, and the Canadian people influenced the changes that national sport organizations (NSO's) made to earn a sense of legitimacy and competency. As the organizations began to grow in size, more organizational structure was needed and the different NSO's began to see the advantage of becoming more structured with a volunteer board and a paid executive to help make important decisions. Thus, there was pressure for other NSO's to align with current industry trends, and soon all the NSO's adopted similar structures without regard to the effectiveness of that structure for their particular organization or situation.

This process can also be seen in universities that are contemplating the addition of football. Current students and alumni want to attend football games and socialize at these events. Board members and administrators hope to earn additional revenue through the sport. Admissions officers expect to receive more applications because of the addition of a football team. When supporters of a college without football watch a peer institution with football seemingly flourish, they may well conclude that the perceived disadvantage needs to be eliminated. There are a number of potential advantages and disadvantages of decision-making based on institutional theory. One advantage is that institutional theory can identify best practices for a certain field or industry. When one organization is doing well by using a particular practice, other firms can mimic that practice and boost their performance. For instance, in college athletics, a number of "best practices" related to department structure, operations, and compliance have been identified..

One prime example is related to game day security at on-campus athletic venues. Currently, facility managers of major stadiums can use a 38 point checklist for game-day security operations that was developed in the years following the terrorist attacks of September 11, 2001 (Pantera et al., 2003). Institutionalization can also help establish standards or benchmarks against which organizations can measure themselves. For instance, most universities submit to an external accreditation 
process to show others that they meet minimum standards in education and are accountable for their commitment to higher education (Harvey, 2004).

However, one of the major disadvantages to institutionalization is that it may lead to a lack of creativity and increased homogeneity among similar institutions. This can ultimately lead to stagnation and decline within an industry (DiMaggio \& Powell, 1983; Kikulis, 2000). If all universities looked the same and developed the exact same athletic department model, then there would be nothing unique and it would be quite difficult for anyone to gain a competitive advantage in terms of university athletics. In addition, if the major investment of adding football is perceived as the only way to build a sense of community or increase university prestige, then it may stifle the creative thinking of other methods for building community and may limit the resources to fund future community building initiatives.

Another disadvantage is that institutionalization can make it difficult for organizations to make a drastic policy or structural change even if it is ethically correct. For instance, in the southern region of the United States, it took many years of slow change before many universities allowed African Americans to play college football due to institutionalization and social pressures for conformity to the status quo of segregating blacks and whites (Borucki, 2003).

Considering the major investment involved in starting a football program at a university, and the large number of schools who are undertaking this endeavor even in an unfavorable economic climate, it is important to understand the factors underlying these decisions from a strategic perspective. Many university presidents and administrators believe that football can provide major benefits to their university. Exactly what are these benefits and how certain are these universities about actually reaping these them? Why are these benefits so important and is football the only (or best) method for achieving these benefits? Toward the ultimate strategic end of maintaining growth and vibrancy in college athletics, it is important to understand if these motivations are driven by a need to gain a competitive advantage or merely a way of universities to keep up with the status quo.

\section{Method}

\section{Sample}

The sample frame for this study included all NCAA Division I schools that added (or considered adding) football over the past five years. Division I offers the highest level of competition in all of college sports and requires the greatest financial investment for the purpose of funding teams. Eight Division I level universities in the past five years have explored and/or made the decision to add football to their athletic program (see Table 1). The football feasibility studies from six of the eight universities were acquired through inquiry and public records. These included Cleveland State University in Cleveland, OH (Carnegie = Doctoral/Research Universities), Georgia State University in Atlanta, GA (Carnegie = Research Universities), University of South Alabama (South Alabama or USA) in Mobile, AL (Carnegie = Master's Colleges and Universities), Old Dominion University (ODU) in Norfolk, VA (Carnegie = Research Universities), The University of North Carolina at Charlotte (UNC Charlotte; Carnegie = Doctoral/Research Universities) and The University of Texas at San Antonio (UTSA; Carnegie = Master's Colleges and Universities). These are all public universities that offer bachelors, masters, 
and doctoral degrees and have substantial undergraduate enrollments (Carnegie Classifications for enrollment profile range from Majority Undergraduate to Very High Undergraduate). These universities were all established during the 20th century and each has between 14,000 and 30,000 students currently enrolled. All are located in urban or suburban settings and, with the exception of UNC-Charlotte, all carry a Carnegie Classification for size and setting of L4/NR, that is, large four year, primarily nonresidential institutions.

\section{Procedure}

Qualitatively oriented content analysis was employed to assess the perceived benefits of football on campus and the strategic rationale used to substantiate the feasibility of such additions. In this analysis we present a picture of strategies employed by several universities and the way they understand and communicate these strategies. It is important to note that this study is not aimed at testing hypotheses or creating statistical inferences from the data (Miles \& Huberman, 1994), but in exploring reasons cited by universities for adding football and how such thinking shapes and constrains their strategic planning as an organization. Each feasibility study was carefully reviewed and coded for themes related to benefits and strategy. While the feasibility studies were contracted with outside vendors and likely contain some voice of the preparer, according to the methodological sections of these analyses, the reports reflect and represent the voices, attitudes, and perspectives of critical stakeholders on each campus.

Thus, this source of data represents an available, condensed and compiled version of the shared perspectives regarding the desirability and feasibility of football on campus (Kozlowski \& Klein, 2000).

Using procedures outlined by Carley (1993),the analysis of phrases was preferred over individual word counts or frequencies because they better capture broader themes related to values and strategies. Previous literature has identified at least five such themes related to benefits of college football: financial contributions, prestige, sense of community, media exposure, and student recruitment (Goff, 2000; Roy, et al., 2008; Sperber, 2001; Toma, 2003; Zimbalist, 1999). Table 2 displays the definitions of each benefit and a sample phrase that was coded accordingly. Utilizing these concepts, and with openness to other potential benefits that might emerge from the data, individual phrases from each feasibility study were coded and the frequency of each concept was recorded as it appeared in the document (Carley, 1993; Neuman, 2000). The frequency of each of the concepts (by phrase) was recorded for each university and those results were aggregated for the overall study. The counting of concepts helps demonstrate their relative importance, yet is not used for statistical inferences (Berleson, 1952).

Qualitative content analysis of phrases was also used to detect themes regarding strategic orientation, that is, RBV or institutionalization. As reviewed in the theoretical framework, it was assumed that the universities under investigation adopted one of these two strategic perspectives. Using these two themes, phrases from each feasibility study were coded and the frequency of each theme was recorded to demonstrate its relative importance to the overall strategic decision and to understand the rationale for adding football on campus. The frequency of the themes was recorded for each university and those results were aggregated for the overall study. Sample statements reflecting each theme are presented in Table 3. 


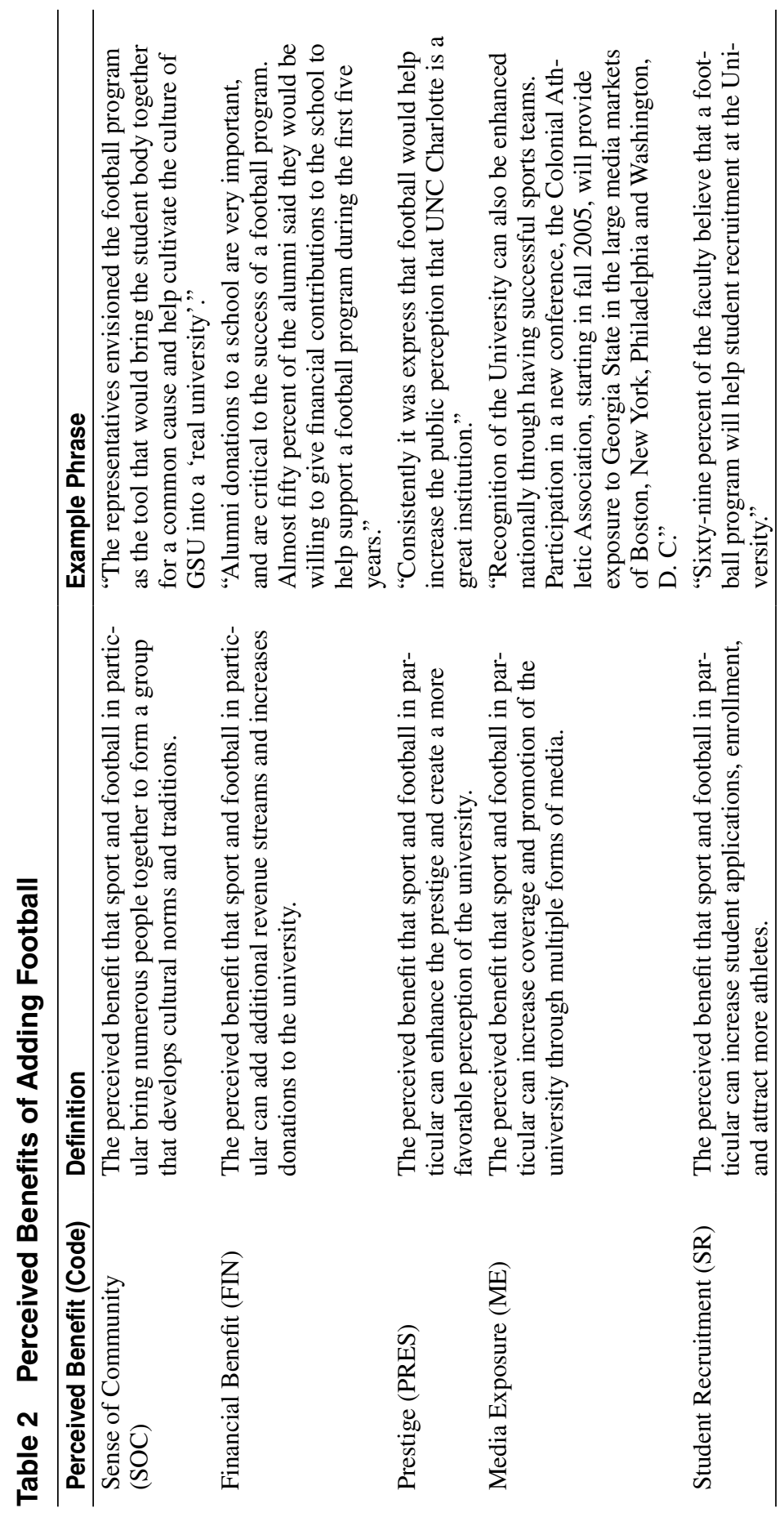




\section{Table 3 Strategic Motivations for a University Adding a Football Program}

\begin{tabular}{lll}
\hline $\begin{array}{l}\text { Strategic } \\
\text { Motivation }\end{array}$ & Definition & Example Phrase \\
\hline $\begin{array}{l}\text { Resourced-Based } \\
\text { View }\end{array}$ & $\begin{array}{l}\text { The motivation of adding } \\
\text { football to create an inimi- } \\
\text { table resource that will } \\
\text { generate multiple benefits } \\
\text { and add value to a univer- } \\
\text { sity. }\end{array}$ & $\begin{array}{l}\text { "A case can be made that the energy } \\
\text { devoted to and generated by athletics can } \\
\text { be a real asset to the "collegiate' aspira- } \\
\text { tions expressed in the University's Strate- } \\
\text { gic Plan..." }\end{array}$ \\
$\begin{array}{ll}\text { The motivation of adding } \\
\text { football because of pres- } \\
\text { sures to conform to a }\end{array}$ & $\begin{array}{l}\text { "The most basic question for the Univer- } \\
\text { certain standard due to a }\end{array}$ \\
& $\begin{array}{l}\text { Texas whose people have an extraordinary } \\
\text { perceived competitive dis- } \\
\text { advantage from not having }\end{array}$ & $\begin{array}{l}\text { be considered a leading university without } \\
\text { sponsoring a successful and visible foot- }\end{array}$ \\
& a football program. & ball program?" \\
\hline
\end{tabular}

The feasibility studies were coded manually by one researcher, and spot coded by the second researcher to check for interrater reliability of coding - both in frequency and in meaning and interpretation of phrases (Marshall \& Rossman, 2006; Neuman, 2000). Coding and themes were discussed until complete agreement was reached. All data were then entered into a spreadsheet to assist with sorting and calculating frequencies of the themes.

\section{Results}

\section{Perceived Benefits}

The thorough content analysis of the feasibility studies showed that sense of community was the leading perceived benefit of adding a college football program. This theme was mentioned 68 times throughout all of the feasibility studies and also led the frequency count of all themes for four of the six universities studied. Student recruitment was the next most mentioned perceived benefit, appearing 31 times throughout the feasibility studies. Financial gain was third (appearing 28 times), followed by prestige ( 26 times), and media exposure (19 times).

Sense of community was a dominant theme overall and the most frequently mentioned value in the feasibility studies for Georgia State University, UNC Charlotte, University of South Alabama, and Cleveland State University. In contrast to these four universities, Old Dominion University's rationale mentioned sense of community twice, but had five mentions each of financial and prestige benefits. UTSA mentioned prestige benefits five times compared with only four mentions of sense of community.

The universities studied felt, in general, that football could provide a stronger sense of community and create a more energetic atmosphere on campus. Georgia State's study stated, "College football programs can play a large role in building a sense of identity generating excitement for/about a school" (pp. 4, Section 3). It 
also stated, "A football program can provide national exposure for the University and develop a sense of community and school spirit among members of the student body" (C.H. Johnson Consulting, 2006, pp. 7, Section 3). South Alabama's President felt that a football program and a school marching band "...serve as a catalyst for a wide range of student life activities, from tailgating to homecoming to any number of related experiences" (University of South Alabama, 2007a). Meanwhile, Cleveland State's feasibility study suggested that, "...football presents the opportunity to provide an enhanced student experience and create an engaged community of students, faculty, staff, alumni, and external community members" (Cleveland State University, 2009, p. 3). Essentially these schools felt that football would enhance student life on campus and also draw alumni and people from the surrounding community to the university (at least on football game days). This enhancement was viewed as a way to make their university more residential and thereby more attractive to nonlocal students.

While sense of community was the most dominant theme, student recruitment was also a major motivation for adding a football program. Facing competition with other schools in their respective states, these universities felt that football would allow them to recruit more men to their university (to try out for and/or play football) and also attract more students in general. UNC Charlotte wanted to use football to connect to potential applicants and argued that "Many applicants and alumni are drawn to universities with football teams in search of the excitement of attending games and other activities"(University of North Carolina at Charlotte, 2008, p. 3). Old Dominion University's survey $(n=4,000)$ revealed that over $80 \%$ of survey respondents felt that football would enhance ODU's ability to recruit students and student athletes (PricewaterhouseCoopers, 2005). These feasibility studies argued that prospective students and student-athletes (football and nonfootball) are attracted by major football programs, and that both applications and enrollment would increase as a result of adding a team..

The universities in this study also indicated that the addition of a football team could garner increased media exposure for the athletic program and the university as a whole. They felt that football programs would receive opportunities to be featured locally and regionally on television, radio, internet sites, and newspapers. UNC Charlotte said, "The addition of football can be a significant element in the branding of the University. Further, successful Division I-A and competitive play at higher levels attracts national attention" (University of North Carolina at Charlotte, 2008, p. 4). This media exposure was also perceived to be related to revenue generation. Georgia State expressed, "The increased energy and attention generated from a significant program expansion should benefit all of the teams, and all of the teams must contribute to the effort to generate audience, revenue and publicity" (C.H. Johnson Consulting, 2006, p. 4 [Section 2]). Thus universities could leverage football to thrust themselves into the media spotlight, and the ensuing recognition that would come from it.

Most of the universities felt that adding a football program would enhance the prestige of the university. UTSA stated that, "increased media exposure [from football] should enhance the University's image and recognition" (Carr Sports Associates, 2006, p. 5). The universities generally sought to be held in a higher regard by other institutions and their surrounding community. UNC Charlotte's feasibility study stated, "...football would help increase the public perception that 
UNC Charlotte is a great institution." (University of North Carolina at Charlotte, 2008 , p. 4). Typically the universities in the study, sought to use football as a way to enhance the perception of the school as a "real university" in the eyes of consumers, potential students, and the community at-large.

In addition to the intangible benefits of adding football, these universities also desired financial benefits. They saw football as a vehicle to increase athletic revenues and increase gifts and donations to the school. "UTSA anticipates that Division I-AA and especially I-A competition would draw increased [financial] support from alumni, the corporate sector, and the community at-large"(Carr Sports Associates, 2006, p. 5). At Cleveland State, the university argued that "FCS football is economically feasible...[and] data from similar universities demonstrates the financial feasibility of adding football" (Cleveland State University, 2009, p. 4). Thus, not only did universities think they could afford to add a major college football program, but they also saw it as a way to bring in additional monies to their universities.

\section{Strategic Motivation}

As for the strategic motivations behind adding football, the feasibility studies indicated phrases related both to a deficit reduction (institutionalization) and a strategic resource (RBV) approach. Phrases indicating a strategic resource approach were found 19 times through the feasibility studies. While not the dominant theme in the feasibility studies, it was still mentioned by most of the schools. For example, Georgia State University noted, "A case can be made that the energy devoted to and generated by athletics can be a real asset to the 'collegiate' aspirations expressed in the University's Strategic Plan..." (C.H. Johnson Consulting, 2006, pp. 3, Section 2). Clearly the language in the statement displays Georgia State's desire to leverage this resource for the perceived benefits the university desires. The University of South Alabama stated, “.... a football program would provide the University a venue through which it could create a marching band program and other student life programs deemed desirable by current and potential students as an outlet for their interest and talents, as well as a public point of pride for their institution..." (University of South Alabama, 2007b, p. 1). Cleveland State University said, "The addition of football would complement the department's other 17 sports and would not detract from existing investments in those sports" (Cleveland State University, 2009 , p. 4). Thus, the universities considered football as a resource that could be strategically leveraged for additional ends.

Phrases that characterized institutionalization or a "keeping up with the Joneses" approach were found 32 times in the feasibility studies. UTSA and UNC Charlotte mentioned these kinds of strategic factors most prominently. For example, in UTSA's feasibility study, it stated, "The athletics competitive market also involves the actual sports contests. The strong desire to win and gain recognition drives the upward spiral of emphasis and expense in salaries, capital outlay and operations." (University of Texas at San Antonio, 2007, p. 5). Schools like UTSA that are involved in NCAA Division I athletics are under pressure to remain competitive athletically with schools in their conferences and division level; they need increasing financial resources to continue to recruit talented athletes and coaches and build a better athletic infrastructure. Georgia State also stated that "Competing 
in Division IAA [now FBS], in the CAA (Colonial Athletic Association), would give the opportunity to compete for a national championship with like-minded programs (C.H. Johnson Consulting, 2006, p. 4). Even though Georgia State currently competes for national championships with similar programs in other sports, football is perceived as having the most prestige and the university feels that the addition of football will allow them to keep pace with other peer universities at the Division I level.

The reports also indicated that the schools felt disadvantaged by not having a football team at their respective universities. For example, UNC Charlotte provided five (5) ramifications of not adding a football program: 1) lack of conference expansion (that is dependent on the potential of increased revenues from football playoff television contracts), 2) possible backlash from alumni who strongly desire a football program, 3) lack of connections to alumni, 4) restricted growth of the athletic program (due to a lack of athletic prestige relative to the academic rigors of the university), and 5) lack of an opportunity to draw the surrounding community to the campus (University of North Carolina at Charlotte, 2008). Thus, universities are feeling pressure to conform not only to student and alumni expectations, but also to the expectations and motivations of schools in their athletic conferences and geographical area. For example, Georgia State University felt that their location in downtown Atlanta, GA near Georgia Tech and within driving distance from the University of Georgia forced them to consider adding football to help their university grow in prominence from an academic and cultural perspective (C.H. Johnson Consulting, 2006). To remain competitive (both on and off the athletic field) with their more prestigious and popular peer institutions, universities like Georgia State, UTSA, and Old Dominion are feeling the pressure to add football.

\section{Discussion}

The narratives and themes that emerged from the football feasibility studies raise awareness of universities' strategic motivations and the most influential factors in their decisions to add a NCAA Division I level football programs to their athletic departments. The types of benefits revealed in this study were fairly consistent with those in other studies (e.g., Roy et al., 2008). Certainly the abundance of these benefits suggests that football is perceived by the institution as being a worthwhile addition to a university's athletic department. Most of the universities in the study felt that the potential benefits-both monetary and nonmonetary-generated by football justified the financial costs associated with the implementation and maintenance of a Division I program. Thus, many of these commuter universities thought that adding football was the best strategy for elevating them to the status of a "real university."

Commuter schools obviously are feeling the pressures to conform to the perceived higher standards and prestige of noncommuter schools. Athletic program offerings and the competitiveness of those offerings are often a perceived as an area of disparity between these nonresidential schools and more "complete" campuses. The presidents and board members of commuter universities seem to think that athletics can provide benefits and improve their reputation more readily than other potential strategic initiatives. They also indicate that initially enhancing athletics will 
eventually aid academics due to the prestige, increased marketing, and increased funding generated by a strong athletic program (cf., Roy et al.; 2008; Zimbalist, 1999). While some commuter schools have increased their on-campus housing to encourage more students to reside on campus (e.g., Old Dominion, UTSA), they also seem to think that a football program will incentivize campus residence and provide the "complete" campus experience for these residential students. Thus, not only will current students be more satisfied with their college experience, but also more prospective students will be attracted to the university.

Though there were multiple perceived benefits of adding a football program, including financial gain, the overwhelming benefit mentioned was the creation of sense of community (SOC) on campus. All of the schools in this study are, in one way or another, in transition from commuter to residential campuses. They want to keep current students living on campus longer, and they want to attract more students who would consider going to a more residential campus. In the minds of the administrators and boards of these universities, they appear to think that football is the best method (or at least one of the best methods) for creating a sense of community that is currently lacking on campus and will bring students, alumni, faculty, staff, and the surrounding community together.

The fact that sense of community was mentioned as a perceived benefit was not necessarily surprising. However, the fact that it was the primary benefit for the group of universities in this study was quite interesting and indicates a departure from the economic and visibility arguments that have dominated previous discussion of the benefits of football (Roy, et al., 2008; Sperber, 2001).

Another interesting finding was the fact that student recruitment was the second most mentioned perceived benefit in all of the feasibility studies. In previous literature, student recruitment was one of the least mentioned perceived benefits of a major college football program (Roy, et al., 2008; Zimbalist, 1999). The universities in this study clearly perceive a need to boost overall applications and enrollment and also possibly attract more males to their campuses either as potential student-athletes or students with an interest in football and major college athletics. The rationale behind adding football for student recruitment seems to be that administrators think that students who have a choice of attending their school or another school that is equal in academic prestige tend to choose the school that offers them the best chance at experiencing college football and athletics in a positive social setting. Thus, if they do not offer football, they are at a recruiting disadvantage relative to those schools that do. These public institutions also may feel pressure to increase enrollment to garner more tuition monies and thereby justify increased funding from the state for academic programs.

Quite surprisingly, the feasibility studies were also completely lacking in discussion or even mention of the educational benefits of football programs. In fact, if one did not know that these were feasibility studies for universities, one would have no indication that they were dealing with matters related to education at all. The reports indicate that universities benefit from football in ways that are not directly related to the educational purpose of the university (such as prestige, monetary benefits from multiple related revenue streams, and improved student recruitment). No mention was made of the potential educational benefits that might accrue to the football players themselves. While attracting more students could increase quality of students who can contribute to the campus educationally, and 
while attracting revenues may eventually trickle down to direct educational benefits, it is clear that these feasibility studies are about increasing institutional, not educational value at these universities (cf., Kretchmar, 2009). Using football for institutional, as opposed to educational enhancements, raises a host of questions about the fit between business and educational objectives and problems associated with this mixed model.

Regarding the strategic motivation and direction for adding football, the institutions use both resource-based view (RBV) and institutional arguments as justification for the possible implementation of the sport. However, the missing elements and themes in the feasibility studies provided just as much insight as the themes that were well represented. For example, while both strategic arguments were present in the feasibility studies, a lack of specific directives for the type of football team, the quality, and the possible strategic niche was apparent. Most schools simply expressed a desire to have a football team and compete in the Football Championship Subdivision with the possibility of moving up to the Football Bowl Subdivision (FBS). Given the depth of the feasibility studies, it was surprising to find that there was no specific definition of a style of play or type of coach they wanted to pursue, or even a unique game day atmosphere that they wanted to create around the football team. Smart and Wolfe's (2000) research suggested that these kinds of elements (a specific style or coach or experience) were the kinds of factors that gave football programs a competitive advantage. If the universities in the study were truly approaching this decision from an RBV perspective, then one would expect more specific language in the studies about how football would create a specific niche and how it would differentiate itself from other schools. The differentiation would give the school a competitive edge because that school would have a resource that was unique and difficult to duplicate (cf. Barney, 1991). While the universities could have used stadium sites and facilities as well as coaching and/or game day atmosphere as points of differentiation that would set them apart from other universities, they failed to include any language that would support a RBV strategy. While the universities seemed to use this view as a justification for creating a football program, the absence of supporting strategic details reinforce the idea that this was clearly the minority strategy.

Approaching the arguments that the universities used to justify football from an institutional view, one would expect to see an emphasis on the areas of need or deficit for each school, and potential alternate solutions for addressing these areas. For instance, if there were a need to create a greater sense of community at the university, there may be multiple ways to accomplish this goal besides football (e.g., more social space for students, informal classes and activities that bring together students and community members, residential housing philosophy changes). It is unclear from their studies whether these universities tried these options and failed or whether they simply overlooked any alternate solutions. This lack of clarity also makes it difficult to determine whether increased pressure to add football was placed on the administration by trustees, donors, alumni, current students, or others.

It is also unclear if the football strategies will be the most effective ones. For example, if the universities want to attract more male students to the university, it is not a foregone conclusion that football is the best and most cost-effective way to achieve this end. Or, if these institutions are seeking ways to make themselves more attractive in a competitive educational marketplace, one could ask why there 
is not more emphasis on educational, rather than athletic initiatives? Yet, in the feasibility studies the universities did not raise these questions or analyze alternative solutions. The narratives, at the very least, could have provided other methods for solving problems such as enhancing the sense of community through other athletic programs already on campus, creating better facilities, adopting a better marketing and promotions strategy, or even possibly changing athletic conferences. Instead, football is identified as the cure-all for the universities' issues.

This can be problematic for universities because it fosters myopic thinking regarding solutions to key university issues. This myopic behavior imitates the actions of other schools rather than motivating and utilizing the creativity of university personnel to address the challenges of the university in a competitive marketplace. If sponsoring football at a large commuter campus turns out to be a "best practice," such conformist thinking will turn out to be shrewd strategy. If it is not, a school will have wasted valuable time and other resources that could have been put to better use in their unique situation.

An additional point of discussion is that the stated versus real motives for adding football cannot be ascertained through the method used in this study. One must assume that the feasibility studies represent the true intentions of the institution. It is possible, however, that presidents and other stakeholders may have additional motives or hidden agendas that were not made public, as university presidents must deal with the pressures of moving forward with these decisions despite conflicting motives by external stakeholders such as board members and boosters (Knight Commission (2009). Thus, the immediate causes for studying the feasibility of adding football may transcend the values identified in this study. Feasibility studies, in fact, may be exercises related to decisions that, for the most part, have already been made, given the pressures that presidents face. Nevertheless, these pressures are exerted by individuals who perceive value in athletics generally and football specifically. These individuals too may be thinking primarily in RBV or institutional terms.

Another item deserves mention. Strikingly, the feasibility studies contained very little discussion regarding the possible negative consequences of adding a football team. Narratives provided extensive detail regarding the possible benefits from a football program, but they seemed to gloss over possible problems such as the difficulty of managing in excess of one hundred male athletes, escalating costs of operating football in the long term, increased student binge drinking on game day, and student perceptions of special treatment of football players (Bormann \& Stone, 2001; Glassman, Werch, Jobli, \& Bian, 2007; Rees \& Schnepel, 2009). In short these studies did not underline the fact that it may not always be wise or fiscally responsible for universities to try to "Keep up with the Jones."

Interestingly, as stated earlier, this may also be why so much of the discussion on the benefits of football in these reports is focused on creating a sense of community rather than the financial benefits accrued from adding football on campus. Like many economic impact arguments surrounding sport events and facilities, universities may be realizing that their constituents are not buying in to the financial arguments in support of football. As Howard and Crompton (2004) argue, "Increased public skepticism with the contention that substantial economic returns accrue from such investments does not necessarily mean subsidies should not be forthcoming. Rather, it means the proponents of public subsidies are required to demonstrate that 
there are alternate sources of spillover benefits that justify them" (p. 161). In other words, can a university's annual subsidy of over $\$ 2$ million to athletics be justified on grounds other than economic impact? In these feasibility studies, the sense of community, media exposure, and other indirect benefits of football are certainly being touted as important, maybe even critical, justifications for the addition of football, perhaps because these benefits are the most important to the university as a whole, or perhaps because they are the most palatable.

\section{Conclusion and Directions for Future Research}

This study examined the strategic motives and perceived benefits sought by NCAA Division I universities when adding football to their commuter campuses. While the content analysis revealed that there were instances of RBV and institutionalization, there was no one clear strategic motivation for the addition of football. However, it appeared that institutionalization was a greater factor for universities than RBV. Many of the peer institutions of the universities in this study either had football in place or were making plans to add football. Thus, when these universities observed others going through this process, it provided strong impetus for them also to pursue the same strategy.

In terms of future directions for research, a longitudinal study of these universities would definitely broaden the understanding of the issue. For example, it would be informative to follow-up with the universities (e.g., interview or survey administrators, faculty, athletic staff, and students and/or conduct economic impact analyses) to determine how successful they were in adding football and test whether they were able to reap the benefits they perceived they would. Most often universities invest considerable effort in examining the feasibility with no review or evaluation after implementation; this would be an insightful area of inquiry. In addition, while the sample size for this study was purposive in investigating schools of similar size and market niche, such a design limited the sample size and scope. It may add value to investigate other schools in Division II and III of the NCAA and possibly NAIA schools to examine similarities/differences in the perceived benefits of football. Finally, to examine the institutionalization of football, it would be helpful to investigate universities that perceived similar deficits on campus (e.g., lack of community, low male enrollment), but instead decided to use other resources (i.e., not football) to address these challenges. It may be possible that other schools were able to identify other effective strategic resources to creatively address their issues on campus, and those resources should be examined from a competitive advantage perspective.

Universities that are pondering the addition of football to their athletic programs must proceed cautiously, carefully, and have a true strategic direction guiding their decision. First, schools must be aware and open with all the facts and details concerning the risks and rewards of adding football, and make a sound decision that is best for all stakeholders of the universities (e.g., students, faculty, staff, alumni). For instance, students may be concerned with fee increases, while faculty and staff might have concerns about how funding tradeoffs affect academics. Schools should consider input from all of these groups. Second, while football may be indeed be a strategic resource in some contexts (i.e., of value, nonimitable), it is imperative that 
universities not automatically turn to this resource just because it has been effective for other universities. The sport of football is a popular and attractive investment for universities that seek financial gain, media exposure, and prestige. However, administrators must not be locked into institutionalization or "Keeping up with the Jones's." Instead they need to be diligent not to look only at one sport, facility, or initiative as the solution to their problems. By looking beyond football, schools may be able to identify other resources that would be truly strategic and give them the competitive edge that they seek in a crowded marketplace.

\section{References}

Armstrong, K. (2009). Hofstra Eliminates 72-Year Old Program. The New York Times, (December 3, 2009). Retrieved from http://www.nytimes.com/2009/12/04/sports/ ncaafootball/04hofstra.html

Auh, S., \& Menguc, B. (2009). Broadening the scope of the resource-based view in marketing: The contingency role of institutional factors. Industrial Marketing Management, 38(7), 757-768.

Barney, J. (1991). Firm resources and sustained competitive advantage. Journal of Management, 17(1), 99-120.

Berleson, B. (1952). Content analysis in communication research. New York: Free Press.

Bormann, C.A., \& Stone, M.H. (2001). The effects of eliminating alcohol in a college stadium: The Folsom Field beer ban. Journal of American College Health, 50(2), 81.

Borucki, W. (2003). "You're Dixie's Football Pride": American college football and the resurgence of Southern identity. Identities (Yverdon), 10(4), 477-494.

Johnson Consulting, C.H. (2006). Football Program Strategy Assessment. Atlanta, GA.

Carley, K. (1993). Coding choices for textual analysis: A comparison of content analysis and map analysis. Sociological Methodology, 23, 75-126.

Carr Sports Associates. (2006). UTSA Athletics Feasibility Study. San Antonio, TX: University of Texas San Antonio.

Cleveland State University. (2009). Cleveland State University football feasibility study. Cleveland, OH: Cleveland State University.

DiMaggio, P.J., \& Powell, W.W. (1983). The iron cage revisited: Institutional isomorphism and collective rationaliy in organizational fields. American Sociological Review, 48(2), $147-160$.

Fahy, J. (2000). The resource-based view of the firm: Some stumbling-blocks on the road to understanding sustainable competitive advantage. Journal of European Industrial Training, 24(2/3/4), 94-104.

FitzGerald, T. (2009). Stanford athletics cuts 21 posts. San Francisco Chronicle, D-5. Retrieved from http://articles.sfgate.com/2009-02-26/sports/17188844_1_staff-cutsendowment-staff-members

Glassman, T., Werch, C.E., Jobli, E., \& Bian, H. (2007). Alcohol-Related fan behavior on college football fame day. Journal of American College Health, 56(3), 255-260.

Goff, B. (2000). Effects of university athletics on the university: A review and extension of empirical assessment. Journal of Sport Management, 14(2), 85.

Grillo, J. (2007). Are you ready for some football? Georgia Trend, 22, 18-25.

Harvey, L. (2004). The power of accreditation: Views of academics. Journal of Higher Education Policy and Management, 26(2), 207-223.

Howard, D., \& Crompton, J.L. (2004). Financing Sport (2nd ed.). Morgantown, WV: FIT.

Kikulis, L.M. (2000). Continuity and change in governance and decision making in national sport organizations: Institutional explanations. Journal of Sport Management, 14(4), 293. 
Knight Commission on Intercollegiate Athletics. (2009). Quantitative and qualitative research with Football Bowl Subdivision university presidents on the costs and financing of intercollegiate athletics: Report of findings and implications. Baltimore, MD: Art \& Science Group, LLC.

Kozlowski, S.W.J., \& Klein, K.J. (2000). A multilvel approach to theory and research in organizations: Contextual, tempora, and emergent process. In S.W.J. Kozlowski \& K.J. Klein (Eds.), Multilvel theory, research, and methods in organization: Foundations, extensions, and new directions (pp. 3-90). San Francisco: Jossey-Bass.

Kretchmar, R.S. (2009). Assessment of Colombo's education argument. Journal of Intercollegiate Sport, 2, 184-201.

Lavelle, L. (2010). University Endowments: Worst year since depression. Bloomberg Business Week. Retrieved from http://www.businessweek.com/bschools/content/jan2010/ bs20100127_360651.htm

Longman, J. (2009). As costs of sports rise, students balk at fees. The New York Times, (May 29, 2009). Retrieved from http://www.nytimes.com/2009/05/30/sports/30colleges.html

Maher, J. (2009, December 9, 2009). In football, Horns are nation's biggest cash cow, Austin American-Statesman, p. C01.

Marshall, C., \& Rossman, G.B. (2006). Designing qualitative research (4th ed.). Thousands Oaks, Calif.: Sage Publications.

Miles, M.B., \& Huberman, A.M. (1994). Qualitative data analysis: An expanded sourcebook (2nd ed.). Thousand Oaks, CA: Sage Publications, Inc.

Consulting, N.A.C.D.A. (2007). NACDA Consulting Report: Texas A\&M Corpus Christi (pp. 1-10). Corpus Christi: NACDA.

NCAA. (2009). 2004-2008 NCAA revenues and expenses of Division I intercollegiate athletics program report. Indianapolis, IN: National Collegiate Athletic Association.

Neuman, W. (2000). Social research methods: Qualitative and quantitative approaches (4th ed.). Boston, MA: Allyn and Bacon.

Oliver, C. (1997). Sustainable competitive advantage: Combining institutional and resourcebased views. Strategic Management Journal, 18(9), 697-713.

Pantera, I., Matthew, J., Accorsi, R., Winter, C., Gobeille, R., Spyros, G., et al. (2003). Best practices for game day security at athletic and sport venues. The Sport Journal, 6(4). Retrieved from http://www.thesportjournal.org/article/best-practices-game-daysecurity-athletic-sport

PricewaterhouseCoopers. (2005). Old Dominion Football Assessment. Norfolk, VA: Old Dominion University.

Priem, R.L., \& Butler, J.E. (2001). Is the resource-based "view" a useful perspective for strategic management research? Academy of Management Review, 26(1), 22-40.

Rees, D.I., \& Schnepel, K.T. (2009). College football games and crime. Journal of Sports Economics, 10, 68-87.

Roy, D.P., Graeff, T.R., \& Harmon, S.K. (2008). Repositioning a university through NCAA Division I-A football membership. Journal of Sport Management, 22(1), 11-29.

Smart, D.L., \& Wolfe, R.A. (2000). Examining sustainable competitive advantage in intercollegiate athletics: A resource-based view. Journal of Sport Management, 14(2), 133-153.

Sperber, M. (2001). Beer and circus: How big-time college sports has crippled undergraduate education (1st Owl Books ed. ed.). New York: Owl Books.

Toma, D. (2003). Football U: Spectator sports in the life of the American university. Ann Arbor, MI: University of Michigan Press.

United States Department of Education. (2008). Equity in Athletics disclosure website Retrieved January 28, 2010, from http://ope.ed.gov/athletics/

University of North Carolina at Charlotte. (2008). UNC Charlotte football feasibility committee recommendation to the chancellor. Charlotte, NC: UNC Charlotte. 
University of South Alabama. (2007a). Q\&A Interview with the USA President on NCAAsanctioned football at the University. The Vanguard, (November 16, 2007). Retrieved from http://www.southalabama.edu/footballproposal/resolution.html

University of South Alabama. (2007b). Resolution: NCAA football and marching band Retrieved February 11, 2010, from http://www.southalabama.edu/footballproposal/ resolution.html

University of Texas at San Antonio. (2007). Athletics Feasibility Study. San Antonio, TX: University of Texas at San Antonio.

Wernerfelt, B. (1984). A resource-based view of the firm. Strategic Management Journal, 5(2), 171-180.

Zimbalist, A.S. (1999). Unpaid professionals: Commercialism and conflict in big-time college sports. Princeton, NJ: Princeton University Press. 